\title{
DESKRIPSI KEJADIAN MALARIA DI KECAMATAN CEMPAKA
}

\author{
Abdul Khair, Noraida \\ Poltekkes Kemenkes Banjarmasin Jurusan Kesehatan Lingkungan \\ Jl. H. MistarCokrokusumo No. 1A Kota Banjarbaru \\ e-mail :ulunkhair@gmail.com
}

\begin{abstract}
Based on the data obtained from Puskesmas Cempaka, it is known that malaria is an endemic disease in the Kecamatan Cempaka. The cases of malaria in the Kecamatan Cempaka in 2011, 2012, and 2013 respectively were 58, 60, and 61. Case Fatality Rate (CFR) of malaria in the Kecamatan Cempaka in 2013 was 3.18\%. This study aimed to describe the distribution of malaria incidence by age, sex, place of residence, history of the scene, and the time of occurrence. This research is descriptive. The sample is the malaria patients who were living in the Kecamatan Cempaka, as many as 61 people. The results showed entire that the age of patients ranged from 8 to 63 years with an average of 29 years. The men are most affected by malaria (95\%). Most malaria patients (49\%) came from the Kelurahan Sei.Tiung. All the history of malaria incidence derived from outside the Kecamatan Cempaka, because most patients go home after work in the KabupatenTanah Bumbu (29\%). Peak incidence of malaria is occurred in May of 2013 (27\%). Epidemic of malaria has the potential to occur in the Kecamatan Cempaka due to the presence of Anopheles. Therefore, people need to avoid being bitten by Anopheles. The methods such as using the mosquito net while sleeping at night.
\end{abstract}

Keywords: malaria incidence; Kecamatan Cempaka

\begin{abstract}
Abstrak: Berdasarkan data yang diperoleh dari Puskesmas Rawat Inap cempaka, diketahui bahwa malaria merupakan penyakit endemis di wilayah Kecamatan Cempaka. Kasus malaria di Kecamatan Cempaka pada tahun 2011, 2012, dan 2013 secara berturut-turut adalah 58, 60, dan 61 orang. Case Fatality Rate (CFR) malaria di Kecamatan Cempaka tahun 2013 adalah 3,18\%. Penelitian ini ditujukan untuk mendeskripsikan distribusi kejadian malaria menurut umur, jenis kelamin, tempat tinggal, riwayat lokasi kejadian, dan waktu terjadinya. Penelitian ini merupakan penelitian deskriptif. Sampel merupakan seluruh penderita malaria yang bertempat tingal di wilayah Kecamatan Cempaka, yaitu sebanyak 61 orang. Hasil penelitian menunjukkan bahwa umur penderita berkisar antara 8 s.d. 63 tahun dengan rata-rata 29 tahun, laki-laki paling banyak terkena malaria (95\%). Penderita malaria kebanyakan (49\%) berasal dari Kelurahan Sei. Tiung. Semua riwayat kejadian malaria berasal dari luar wilayah Kecamatan Cempaka, penderita terbanyak karena pulang setelah bekerja di wilayah Kabupaten Tanah Bumbu (29\%). Kejadian malaria terjadi puncaknya pada bulan Mei tahun 2013 (27\%). Kejadian Luar Biasa (KLB) malaria berpotensi terjadi di Kecamatan Cempaka karena terdapatnya Anopheles sebagai vektor malaria. Oleh karena itu masyarakat perlu menghindari tergigit nyamuk Anopheles dengan cara diantaranya menggunakan kelambu saat tidur di malam hari.
\end{abstract}

Kata kunci: Kejadian Malaria; Kecamatan Cempaka

\section{PENDAHULUAN}

Malaria dapat dikatakan sebagai penyakit kuno, dalam arti bahwa penyakit ini sudah sejak lama ditemukan, namun hingga sekarang masih ditemukan cukup tinggi. Reemerging disease digunakan sebagai istilah bahwa malaria merupakan penyakit yang menular kembali secara massal. Di Indonesia, malaria pertama kali dilaporkan oleh tentara Belanda, yaitu adanya laporan wabah di Cirebon pada tahun 1852-1854. Pemberantasan malaria dimulai sejak tahun 1911(1).

Penyebab penyakit malaria adalah genus plasmodia family plasmodiidae dan ordo coccidiidae. Plasmodium falcifarum, Plasmodium vivax, Plasmodium malariae, dan Plasmodium ovale, merupakan 4 macam parasit malaria di Indonesia saat ini. Infeksi campuran (mix infection) merupakan istilah yang menggambarkan 
seorang penderita yang dihinggapi oleh lebih dari satu jenis plasmodium.

Seseorang dapat tertular malaria karena gigitan nyamuk Anopheles betina yang membawa plasmodium setelah menggigit orang lain yang menderita malaria. Diketahui bahwa dari 46 species nyamuk Anopheles terdapat 20 species yang dapat berperan sebagai vektor (penular) penyakit malaria(2).

Upaya yang biasa dilakukan dalam rangka pemberatasan malaria, diantaranya melalui pemberatasan nyamuk Anopheles dewasa sebagai vektor malaria yang dilanjutkan dengan pengobatan pada suspect maupun penderita positif malaria. Tidak lainnya adalah dengan penyemprotan rumah dan lingkungan sekitarnya dengan insectisida. Sedangkan untuk membunuh larva nyamuk Anopheles dilakukan baik melalui cara kimiawi (larvasida) maupun cara hayati (agen predator).

Dalam Millenium Development Goals (MDG's), malaria menjadi salah satu penyakit yang menjadi bagian komitmen global. Penyebaran malaria pada tahun 2015 ditargetkan terhenti dan insidensi dapat dikurangi. Indikator keberhasilan dilihat dari penurunan prevalensi dan kematian akibat malaria(3). Di Indonesia, sejak tahun 2009 pemerintah telah menetapkan melalui Keputusan Menteri Kesehatan No.293/MENKES/SK/IV/2009 tanggal 28 April 2009 bahwa upaya pengendalian malaria dilakukan dalam rangka eliminasi malaria di Indonesia(4).

Kecamatan Cempaka adalah salah satu kecamatan yang berada di Kota Banjarbaru Provinsi Kalimantan Selatan. Berdasarkan data yang diperoleh dari Puskesmas Rawat Inap cempaka, diketahui bahwa malaria merupakan penyakit endemis di wilayah Kecamatan Cempaka. Tercatat bahwa kasus malaria di Kecamatan Cempaka pada tahun 2011, 2012, dan 2013 secara berturut-turut adalah 58, 60, dan 61 orang(5). Case Fatality Rate (CFR) malaria di Kecamatan Cempaka tahun 2013 adalah 3,18 persen. Kejadian Luar Biasa (KLB) dapat saja terjadi di wilayah ini disebabkan adanya breeding place yang terbentuk karena adanya penambang setempat, baik penambangan pasir/koral maupun penambangan intan.

Secara epidemiologi, penyebaran (distribution) penyakit dapat dideskripsikan menurut orang (person), tempat (place), dan waktu (time). Lebih lanjut penyakit dapat dideskripsikan diantaranya umur, jenis kelamin, tempat tinggal, tempat terjadinya, dan waktu terjadinya suatu penyakit. Studi tentang distribusi sangat bermanfaat dalam banyak hal, di antaranya dapat digunakan untuk mengetahui besarnya beban penyakit (disease burden) pada populasi tertentu, menentukan diagnosis masalah kesehatan pada populasi, dan menetapkan prioritas masalah kesehatan. Ini juga dapat digunakan untuk merumuskan hipotesis tentang determinan penyakit (6).

Berdasarkan uraian di atas, maka penelitian ini ditujukan untuk mendeskripsikan distribusi kejadian malaria menurut umur, jenis kelamin, tempat tinggal, riwayat lokasi kejadian, dan waktu terjadinya.

\section{BAHAN DAN CARA}

Studi ini merupakan studi deskriptif kejadian malaria di Kecamatan Cempaka Kota Banjarbaru tahun 2013. Studi mendeskripsikan kejadian malaria berdasarkan faktor orang, tempat, dan waktu. Populasi penelitian adalah seluruh penderita malaria yang bertempat tinggal di Kecamatan Cempaka Kota Banjarbaru pada tahun 2013. Seluruh anggota populasi diambil sebagai sampel, yaitu sebanyak 61 orang penderita malaria. Data yang dikumpulkan adalah data tentang umur, jenis kelamin, tempat tinggal, riwayat tempat kejadian, dan waktu kejadian setiap penderita malaria di wilayah Kecamatan Cempaka. Pengumpulan data bersumber data sekunder yang diperoleh dari Dinas Kesehatan Kota Banjarbaru, Puskesmas Rawat Inap Cempaka, dan hasil-hasil penelitian terkait. Data-data yang tidak dapat diperoleh secara sekunder dicari dengan melakukan wawancara secara langsung kepada petugas Puskesmas Rawat Inap Cempaka, diantaranya tentang pekerjaan penderita malaria. Data yang dikumpulkan diolah dan disajikan dalam bentuk narasi dan gambar. Bentuk 
penyajian gambar berupa grafik maupun peta. Data dianalisis secara deskriptif.

\section{HASIL DAN PEMBAHASAN}

Berdasarkan hasil pengolahan data dari 61 orang penderita malaria di Kecamatan Cempaka maka dapat diketahui bahwa distribusi umur penderita berkisar antara 8 tahun sampai 63 tahun. Rata-rata umur penderita malaria adalah 29 tahun. Pada umur ini memang potensial untuk terkena penyakit malaria karena pada rata-rata umur tersebut, biasanya kaum laki-laki senang duduk-duduk di luar rumah hingga larut malam. Padahal nyamuk
Anopheles siap setiap waktu menggigit dan mengisap darahnya sambil mengeluarkan kuman plasmodium. Kecamatan Cempaka merupakan wilayah pemukiman yang telah lama sehingga banyak penduduk yang berumur dewasa dan dapat mempunyai kebiasaan begadang di luar rumah hingga larut malam.

Ditinjau dari distribusi menurut jenis kelamin penderita diketahui bahwa lakilaki lebih banyak (95\%) yang menderita penyakit malaria. Distribusi kejadian malaria menurut jenis kelamin penderita seperti Tabel 1.

Tabel 1. Distribusi Kejadian Malaria Menurut Jenis Kelamin Penderita

\begin{tabular}{cccc}
\hline No. & Jenis Kelamin & Jumlah & $\%$ \\
\hline 1. & Laki-laki & 58 & 95 \\
2. & Perempuan & 3 & 5 \\
& Jumlah & 61 & 100 \\
\hline
\end{tabular}

Sumber : PKM Rawat Inap Cempaka, 2013

Pada dasarnya laki-laki memang dimungkinkan untuk lebih banyak menderita malaria dibandingkan perempuan. Hal ini dikarenakan tipe pekerjaan para lelaki tersebut yang penuh risiko. Lakilaki bisa bekerja diantaranya sebagai penambang, dimana letak tempat penambangan berada di hutan-hutan yang biasanya merupakan tempat yang baik bagi berkembangnya nyamuk Anopheles.
Para penambang tersebut sangat potensial terkena penyakit malaria (7).

Berdasarkan data dari Puskesmas Rawat Inap Cempaka diketahui bahwa umur penderita malaria pada tahun 2013 berkisar antara 8 s.d 63 tahun dengan rata-rata 29 tahun dan standar deviasi 10,2 tahun. Pada Tabel 2 ditunjukkan distribusi kejadian malaria menurut umur penderita. Penderita paling banyak berumur antara 10 s.d. 39 tahun (85\%).

Tabel 2. Distribusi Kejadian Malaria Menurut Umur Penderita

\begin{tabular}{cccc}
\hline No. & Kelompok Umur & Jumlah & $\%$ \\
\hline 1. & $0-9$ & 1 & 2 \\
2. & $10-19$ & 9 & 15 \\
3. & $20-29$ & 21 & 34 \\
4. & $30-39$ & 22 & 36 \\
5. & $40-49$ & 5 & 8 \\
6. & $50-59$ & 2 & 3 \\
7. & $60-69$ & 1 & 2 \\
& Jumlah & & 100 \\
\hline
\end{tabular}

Sumber : PKM Rawat Inap Cempaka, 2013

Kondisi ini menunjukkan bahwa penderita berumur produktif (20-39 tahun) paling banyak menderita malaria. Hal tersebut dapat terjadi karena masyarakat umur produktif di kecamatan tersebut biasanya bekerja aktif di luar wilayah. Hal ini diperkuat dengan Tabel 3 yang menunjukkan riwayat lokasi kejadian malaria pada semua penderita pada tahun 2013.

Berdasarkan data yang diperoleh dari Puskesmas Rawat Inap Cempaka 
dapat didistribusikan kejadian malaria menurut riwayat lokasi kejadian dari setiap penderita di Kecamatan Cempaka tersebut. Sebagian besar (29\%) riwayat lokasi tertularnya malaria berasal dari Kabupaten Tanah Bumbu. Petugas program P2 Malaria (Pemberantasan Penyakit Malaria) memberikan keterangan bahwa seluruh (100\%) penderita yang terkena malaria tersebut terkena penyakit malaria dari luar wilayah Kecamatan Cempaka. Para penderita kebanyakan bekerja sebagai penambang di wilayah yang didatanginya dan kembali pulang ke kampung halamannya saat sudah menderita malaria. Tabel 3 menunjukkan distribusi kejadian malaria menurut riwayat lokasi kejadian.

Tabel 3. Distribusi Kejadian Malaria Menurut Riwayat Lokasi Kejadian

\begin{tabular}{clcc}
\hline No. & \multicolumn{1}{c}{ Lokasi } & Jumlah & $\%$ \\
\hline 1. & Tanah Bumbu & 18 & 29 \\
2. & Banjar & 8 & 13 \\
3. & Hulu Sungai Selatan & 14 & 22 \\
4. & Tanah Laut & 6 & 10 \\
5. & Lainnya & 15 & 24 \\
& Jumlah & 61 & 100
\end{tabular}

Sumber : PKM Rawat Inap Cempaka, 2013

Tabel 4 menunjukkan kelurahan asal tempat tinggal penderita malaria di Kecamatan Cempaka. Diketahui bahwa asal bertempat tinggal penderita paling banyak (49\%) dari Kelurahan Sei. Tiung dan yang paling sedikit (5\%) berasal dari Kelurahan Palam.

Tabel 4. Distribusi Kejadian Malaria Menurut Asal Tempat Tinggal Penderita

\begin{tabular}{clccc}
\hline No. & & Kelurahan & Jumlah & $\%$ \\
\hline 1. & Cempaka & 17 & 28 \\
2. & Sei. Tiung & 30 & 49 \\
3. & Bangkal & 11 & 18 \\
4. & Palam & 3 & 5 \\
& Jumlah & 61 & 100
\end{tabular}

Sumber : PKM Rawat Inap Cempaka, 2013

Hal ini menunjukkan bahwa penduduk umur produktif yang berasal dari Kelurahan Sei. Tiung mempunyai kebiasaan mencari pekerjaan di luar wilayah. Kondisi ini juga memungkinkan Kelurahan Sei. Tiung menjadi kelurahan yang paling rawan untuk penularan malaria pada penduduk lain di kelurahan tersebut. Upaya pengobatan penderita segera dilakukan dan adanya breeding place nyamuk Anopheles harus lebih diwaspadai.
Pada Gambar 1 ditunjukkan distribusi kejadian malaria menurut waktu kejadiannya. Nampak bahwa kejadian malaria di Kecamatan Cempaka pada tahun 2013 mencapai puncaknya pada bulan Mei. Kejadian malaria pada bulan tersebut paling banyak (27\%) dibandingkan kejadian malaria pada bulanbulan lainnya. Hanya pada bulan Agustus dan Oktober 2013 tidak terdapat penderita malaria di Kecamatan Cempaka. 


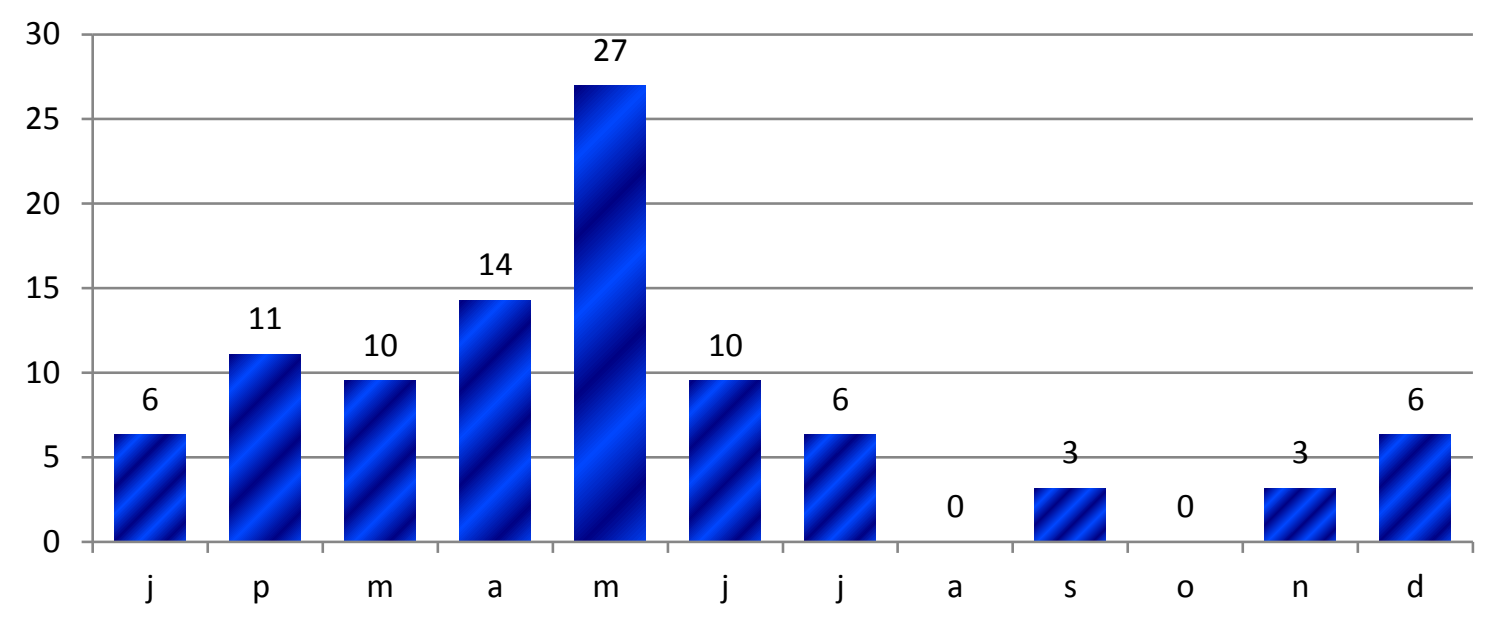

Gambar1. Distribusi Kejadian Malaria Menurut Waktu (bulan) Kejadian

Hasil pemeriksaan mikroskopis dari sediaan darah penderita malaria menunjukkan bahwa jenis plasmodiun yang menyebabkan malaria pada penderita di tahun 2013 adalah Plasmodium falcifarum, Plasmodium vivax, dan Mix Infection. Jenis-jenis plasmodium ditunjukkan pada Gambar 2.

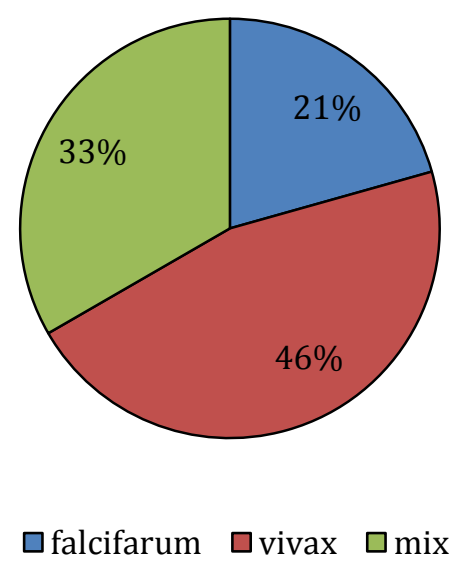

Gambar2. Jenis Plasmodium Penyebab Malaria Di Kecamatan Cempaka

Berdasarkan hasil penelitian Noor (2010), di wilayah Kecamatan Cempaka, species nyamuk Anopheles yang tertangkap yaitu Anopheles nigerrimus, Anopheles flavirostris, Anopheles aconitus. Ketiga species nyamuk ini ditemukan menggigit manusia baik di dalam maupun di luar rumah. Nyamuk-nyamuk ini juga ditemukan di kandang sapi yang terletak sangat berdekatan dengan rumah-rumah penduduk (8).

Keberadaan nyamuk Anopheles sangat tergantung oleh breeding places yang sesuai. Selain itu, suhu dan kelembaban sangat mempengaruhi siklus kehidupannya. Suhu di lokasi penangkapan nyamuk berkisar antara $25^{\circ} \mathrm{C}-30^{\circ} \mathrm{C}$ sedangkan kelembaban berkisar antara 75\%-86\%. Kebanyakan nyamuk Anopheles ditemukan aktif menggigit selain pada jam 20.00-21.00 wita (Anopheles nigerrimus), juga pada jam 02.00-05.00 wita.

Sebagian wilayah merupakan daerah penambangan pasir dan koral. Kegiatan penambangan di wilayah ini menimbulkan lubang-lubang yang biasanya digenangi oleh air terutama pada musim 
hujan dan dapat menjadi breeding place yang sangat baik bagi berkembangnya nyamuk Anopheles.

\section{KESIMPULAN DAN SARAN}

Besarnya kejadian malaria dan adanya kematian karena malaria pada tahun 2013 di Kecamatan Cempaka mengharuskan dilakukannya kesiapsiagaan pengobatan penderita. Terdapatnya Anopheles sebagai vektor penular malaria juga mengharuskan kepada petugas kesehatan melakukan penanggulangan berupa penyemprotan dinding rumah dengan insektisida, misal piretroid atau permetrin. Masyarakat menjaga tidak terdapatnya breeding place yang baik bagi nyamuk Anopheles. Masyarakat, terutama laki-laki, menghindari begadang malam yang dapat memungkinkan tergigit oleh nyamuk Anopheles. Jika upaya-upaya di atas tidak dilakukan dengan baik, maka potensi KLB malaria selalu saja menanti.

\section{KEPUSTAKAAN}

1. Arsin AA. Malaria di Indonesia Tinjauan Aspek Epidemiologi Makassar: Masagena Press ; 2012.

2. Hiswani. Gambaran Penyakit dan Vektor
Malaria di Indonesia Medan: USU Digital Library; 2004.

3. P2B2 PDdI. Epidemiologi Malaria di Indonesia. Buletin Jendela Data dan Informasi Kesehatan Epidemiologi Malaria di Indonesia. 2011; 1.

4. Laihad FJ. Pengendalian Malaria Dalam Era Otonomi dan Desentralisasi Menuju Eliminasi Malaria 2030 di Indonesia. Buletin Jendela Data dan Informasi Kesehatan Epidemiologi Malaria di Indonesia. 2011; 1.

5. Malaria PPP. Data Penderita Malaria (Klinis dan Positif) Banjarbaru: Puskesmas Rawat Inap Cemapaka; 2011-2013.

6. Murti B. Pengantar Epidemiologi Surakarta: Fakultas Kedokteras Universitas Sebelas Maret; 2013.

7. Batulicin F. 10 Kecamatan, 99 Desa Endemik Malaria.

In http://www.fokusbatulicin.com/2011/11/18desa-tanbu-terdeteksi-endemis.html; 2011; Batulicin.

8. Noor E. Komunitas Nyamuk Anopheles. Jurnal Kesehatan Lingkungan. 2010; 7: p. 13-28.

9. P2M\&PL D. Vektor Malaria di Indonesia Jakarta: DepKes RI; 1985. 